\title{
Volatile anesthetics suppress glucose-stimulated insulin secretion in MIN6 cells by inhibiting glucose-induced activation of hypoxia-inducible factor 1
}

Kengo Suzuki, Yoshifumi Sato, Shinichi Kai, Kenichiro Nishi, Takehiko Adachi, Yoshiyuki Matsuo, Kiichi Hirota

Proper glycemic control is one of the most important goals in perioperative patient management. Insulin secretion from pancreatic $\beta$-cells in response to an increased blood glucose concentration plays the most critical role in glycemic control. Several animal and human studies have indicated that volatile anesthetics impair glucose-stimulated insulin secretion (GSIS). A convincing GSIS model has been established, in which the activity of ATP-dependent potassium channels $\left(\mathrm{K}_{\text {ATP }}\right)$ under the control of intracellular ATP plays a critical role. We previously reported that pimonidazole adduct formation and stabilization of hypoxia-inducible factor-1 $\alpha$ (HIF-1 $\alpha$ ) were detected in response to glucose stimulation and that MIN6 cells overexpressing HIF-1 $\alpha$ were resistant to glucose-induced hypoxia. Genetic ablation of HIF-1 $\alpha$ or HIF-1 $\beta$ significantly inhibited GSIS in mice. Moreover, we previously reported that volatile anesthetics suppressed hypoxia-induced HIF activation in vitro and in vivo.

To examine the direct effect of volatile anesthetics on GSIS, we used the MIN6 cell line, derived from mouse pancreatic $\beta$-cells. We performed a series of experiments to examine the effects of volatile anesthetics (sevoflurane and isoflurane) on GSIS and demonstrated that these compounds inhibited the glucose-induced ATP increase, which is dependent on intracellular hypoxia-induced HIF-1 activity, and suppressed GSIS at a clinically relevant dose in these cells. 
2 Volatile anesthetics suppress glucose-stimulated insulin secretion in MIN6 cells by

3 inhibiting glucose-induced activation of hypoxia-inducible factor 1

4

5 Kengo Suzuki ${ }^{1}$, Yoshifumi Sato ${ }^{2}$, Shinichi Kai ${ }^{1}$, Kenichiro Nishi ${ }^{1}$, Takehiko Adachi ${ }^{3}$,

6 Yoshiyuki Matsuo ${ }^{1}$ and Kiichi Hirota ${ }^{1 *}$

$8{ }^{1}$ Department of Anesthesiology, Kansai Medical University, Hirakata 573-1191, Japan

$9{ }^{2}$ Department of Medical Biochemistry, Faculty of Life Sciences, Kumamoto University,

10 Kumamoto, Japan

$11{ }^{3}$ Department of Anesthesia, Tazuke Kofukai Medical Research Institute Kitano Hospital, Osaka,

12 Japan.

13

14 * Corresponding author: Kiichi Hirota; Department of Anesthesiology, Kansai Medical

15 University, 2-3-1 Shin-Machi Hirakata, Osaka 573-1191, Japan. Fax: + 81-72-804-2785E-mail:

16 hif1@mac.com 


\section{Abstract}

Proper glycemic control is one of the most important goals in perioperative patient management.

Insulin secretion from pancreatic $\beta$-cells in response to an increased blood glucose concentration

21 plays one of the most critical roles in glycemic control. Several animal and human studies have

convincing GSIS model has been established, in which the activity of ATP-dependent potassium

channels $\left(\mathrm{K}_{\mathrm{ATP}}\right)$ under the control of intracellular ATP plays a critical role. We previously

reported that pimonidazole adduct formation and stabilization of hypoxia-inducible factor-1 $\alpha$

$26(\mathrm{HIF}-1 \alpha)$ were detected in response to glucose stimulation and that MIN6 cells overexpressing

HIF-1 $\alpha$ were resistant to glucose-induced hypoxia. Genetic ablation of HIF-1 $\alpha$ or HIF-1 $\beta$

significantly inhibited GSIS in mice. Moreover, we previously reported that volatile anesthetics

suppressed hypoxia-induced HIF activation in vitro and in vivo. To examine the direct effect of

volatile anesthetics on GSIS, we used the MIN6 cell line, derived from mouse pancreatic $\beta$-cells.

31 We performed a series of experiments to examine the effects of volatile anesthetics (sevoflurane and isoflurane) on GSIS and demonstrated that these compounds inhibited the glucose-induced 
33 ATP increase, which is dependent on intracellular hypoxia-induced HIF-1 activity, and

34 suppressed GSIS at a clinically relevant dose in these cells. 
Proper glycemic control is one of the most important goals in perioperative patient management

response to an increase in the blood glucose concentration plays a critical role in glycemic

41 control.

Several animal and human studies have indicated that volatile anesthetics such as halothane,

enflurane, isoflurane, and sevoflurane impair insulin secretion in response to glucose

administration. The blood glucose concentration reflects an elaborate balance between the generation and utilization of glucose; this is determined by the secretion of, and the resistance to, insulin. This internal balance, however, can be disturbed by external factors such as surgical insults and the drugs used for anesthetic management.

A convincing model of glucose-induced insulin secretion has been established, based on 
50 intracellular ATP concentration ([ATPi]) plays a crucial role in GSIS. When the extracellular

51 glucose concentration increases, pancreatic $\beta$-cell metabolism accelerates, leading to an increase

52 in [ATPi]. As a result of these metabolic changes, the activity of ATP-dependent potassium

53 channels $\left(\mathrm{K}_{\mathrm{ATP}}\right)$ decreases; this causes membrane depolarization to the threshold potential at

54 which voltage-dependent calcium channels open, allowing $\mathrm{Ca}^{2+}$ influx. The ensuing increase in

55 cytosolic $\mathrm{Ca}^{2+}$ concentration triggers exocytosis of insulin-containing vesicles. We and others

56 have demonstrated that glucose induced a high level of $\mathrm{O}_{2}$ consumption (Kurokawa et al. 2015),

57 resulting in intracellular hypoxia that was strong enough to activate the hypoxia-inducible factors

58 (HIF), HIF-1 and HIF-2, in pancreatic $\beta$-cells (Bensellam et al. 2012; Sato et al. 2011). A

59 series of in vivo studies has demonstrated that volatile anesthetics, including halothane,

60 isoflurane, sevoflurane, and desflurane suppressed GSIS, resulting in a dysregulation of the

61 blood glucose concentration (Lipshutz \& Gropper 2009; Martinez et al. 2007; Tanaka et al.

62 2011a). In addition, several reports indicated that these anesthetics disturbed GSIS by

63 inhibiting $\mathrm{K}_{\mathrm{ATP}}$ closure (Tanaka et al. 2009). Genetic ablation of the HIF- $1 \alpha$ or HIF-1 $\beta$ gene

64 was shown to reduce GSIS in mice (Cheng et al. 2010; Gunton et al. 2005; Pillai et al. 2011).

65 Moreover, we previously reported that halothane, sevoflurane, and isoflurane suppressed 
66 hypoxia-induced activation of HIFs in vitro and in vivo (Itoh et al. 2001; Kai et al. 2014; Tanaka

67 et al. 2011b).

68 The present series of experiments examined the effects of volatile anesthetics (sevoflurane and

69 isoflurane) on GSIS and demonstrated that both anesthetics inhibited the glucose-induced

70 increase in [ATPi], which is dependent on intracellular hypoxia-induced HIF-1 activity, and

71 suppressed GSIS at a clinically relevant dose in the mouse MIN6 insulinoma pancreatic $\beta$-cell

72 line. 
74 Materials and methods

75

\section{Cells and cell culture}

\section{Reagents}

Isoflurane was obtained from Dainippon Sumitomo Pharma Co., Ltd. (Osaka, Japan) and sevoflurane was from Maruishi Pharmaceutical Co., Ltd. (Osaka, Japan). Oxygen (Taiyo Nippon Sanao, Wakayama, Japan), and nitrogen (Taiyo Nippon Sanso) were also used. An inhibitor of HIF, 5-[1-(phenylmethyl)-1H-indazol-3-yl]-2-furanmethanol (YC-1), the HIF $\alpha$ hydroxylase inhibitor, dimethyloxaloylglycine (DMOG), the selective $\mathrm{K}_{\text {ATP }}$ (Kir6 subunit) blocker, glibenclamide, and the activator, diazoxide, were all obtained from Abcam (Cambridge, MA). n-Propyl gallate (nPG; 3,4,5-trihydroxybenzoic acid propyl ester), the mitochondrial uncoupler, carbonyl cyanide m-chlorophenylhydrazone (CCCP), sucrose, and maltose were all obtained from Sigma Aldrich (St. Louis, MO).

The mouse insulinoma MIN6 and MIN7 cell lines were a gift from Dr. J. Miyazaki (Osaka 
$88 \mathrm{CO}_{2}$ and 95\% air in Dulbecco's modified Eagle's medium (DMEM) (Gibco, Grand Island, NY)

89

90

91

\section{Treatment with volatile anesthetics}

92 Cells were maintained in an airtight chamber or work-station (AS-600P, AsOne, Japan) perfused with mixed air (MODEL RK120XM series, Kofloc, Kyotanabe, Japan) with or without each test anesthetic, delivered by a specialized vaporizer within the open circuit. The concentrations of gases and anesthetics in the incubator were monitored during each treatment using an anesthetic

\section{Measurement of insulin concentration}

Insulin secretion into the culture medium from MIN6 cells was measured using the Mouse

Insulin H-type ${ }^{\mathrm{TM}}$ enzyme-linked immunosorbent assay kit (Shibayagi Co. Ltd., Shibukawa, 
103 Japan), according to the manufacturer's protocol (Matsumoto et al. 2012). Briefly, MIN6 cells

104 were cultured for $30 \mathrm{~min}$ in Krebs-Ringer bicarbonate HEPES (KRBH) buffer (140 mM NaCl,

$1053.6 \mathrm{mM} \mathrm{KCl}, 0.5 \mathrm{mM} \mathrm{NaH}_{2} \mathrm{PO}_{4}, 0.5 \mathrm{mM} \mathrm{MgSO}_{4}, 1.5 \mathrm{mM} \mathrm{CaCl}_{2}, 2 \mathrm{mM} \mathrm{NaHCO} 3,10 \mathrm{mM}$

106 HEPES, $0.1 \%$ bovine serum albumin) containing $40 \mathrm{mg} / \mathrm{dl}$ glucose. Then, the KRBH buffer

107 was changed to one containing the indicated concentration of glucose, and the cells were

108 cultured for $10 \mathrm{~min}$ or $1 \mathrm{~h}$. The KRBH buffer was collected and subjected to insulin

109 measurement. The cells on the dish were washed once with phosphate-buffered saline, lysed,

110 and collected by scraping. The cells were sonicated and the protein concentration was

111 determined using a protein assay kit (BioRad Laboratories, Hercules, CA), with bovine serum

112 albumin as the standard. The insulin concentration of the buffer was normalized to the total cell

113 protein level. The results were normalized to the concentration of control samples of each

114 independent experiment and the normalized values were demonstrated as insulin secretion ratio.

115 Cytotoxicity assay

116 Changes in the cellular viability of MIN6 cells were determined by the CellTiter 96 ${ }^{\mathrm{TM}}$ AQueous

117 One Solution cell proliferation assay (Promega) (Kai et al. 2012). The assay uses a

118 colorimetric method to determine the number of viable cells in cytotoxicity assays. MIN6 cells 
119 were seeded in 96-well plates at a density of $2.0 \times 10^{4}$ per well (in $100 \mu \mathrm{l}$ medium). After $24 \mathrm{~h}$, cells were exposed to isoflurane or sevoflurane for $8 \mathrm{~h}$. MTS ([3-(4,5-dimethylthiazol-2-yl)-5-

121 (3-carboxymethoxyphenyl)-2-(4-sulfophenyl)-2H-tetrazolium, inner salt]/phenazine ethosulfate

122 (PES) solution was added and incubation was continued for $30 \mathrm{~min}$. The absorbance of individual wells was then measured at a wavelength of $490 \mathrm{~nm}$ corrected to $650 \mathrm{~nm}$ using a

124 Thermo Max ${ }^{\mathrm{TM}}$ microplate reader (Molecular Devices, Sunnyvale, CA). Assays were performed at triplicate at least twice. Data were expressed as mean \pm standard deviation (SD). Assessment of apoptosis in MIN6 cells Apoptosis was measured with the Apo-ONE ${ }^{\text {TM }}$ Homogeneous Caspase-3/7 Assay (Promega, Madison, WI, USA) according to the manufacturer's protocol. The assay contains proflourescent rhodamin 110 (Z-DEVD-R110) which serves as a substrate for both Caspase-3 and -7. MIN6 cells were seeded in 96-well plates at a density of $2.0 \times 10^{4}$ per well (in $100 \mu 1$ medium). After $24 \mathrm{~h}$, cells were exposed to isoflurane or sevoflurane. After an additional $8 \mathrm{~h}$

132 of incubation, fluorescence was measured with Ensopire ${ }^{\mathrm{TM}}$ plate reader (PerkinElmer, Waltham, MA) to determine the Caspase-3/7 activity. Assays were performed at triplicate at least twice.

Data were expressed as mean \pm standard deviation (SD). 
136 The total OCR was measured as described previously (Kai et al. 2012; Zhang et al. 2007).

137 Cells were trypsinized and suspended at $1 \times 10^{7}$ cells per $\mathrm{ml}$ in DMEM containing $10 \%$ FBS and

$13825 \mathrm{mM}$ HEPES buffer. For each experiment, equal numbers of cells suspended in $1 \mathrm{ml}$ were

139 pipetted into the chamber of an Oxytherm electrode unit (Hansatech Instruments, Norfolk,

140 United Kingdom), which uses a Clark-type electrode to monitor the dissolved $\mathrm{O}_{2}$ concentration

141 in the sealed chamber over time. The data were exported to a computerized chart recorder

142 (Oxygraph; Hansatech Instruments) that calculated the OCR. The temperature was maintained at

$14325^{\circ} \mathrm{C}$ during measurement. The $\mathrm{O}_{2}$ concentration in $1 \mathrm{ml}$ of DMEM medium without cells was

144 also measured over time to provide background values. $\mathrm{O}_{2}$ consumption experiments were

145 repeated at least thrice. Data were expressed as mean \pm standard deviation (SD) (Kai et al.

146 2012). MIN6 cells were pre-exposed to the volatile anesthetics isoflurane and sevoflurane for

147 1h. Cells were harvested and OCR measurement was performed in a working chamber.

148 CCCP was added just before OCR measurement. 
150 Whole-cell lysates were prepared as described previously (Goto et al. 2015; Tanaka et al. 2010).

151 In brief, these were prepared using ice-cold lysis buffer (0.1\% SDS, 1\% Nonidet P-40 [NP-40], 5

$152 \mathrm{mM}$ EDTA, $150 \mathrm{mM} \mathrm{NaCl}, 50 \mathrm{mM}$ Tris-Cl [pH 8.0], 2 mM DTT, 1 mM sodium orthovanadate,

153 and Complete Protease Inhibitor ${ }^{\mathrm{TM}}$ [Roche Diagnostics, Tokyo, Japan]) using a protocol

154 described previously (Kai et al. 2012). Samples were centrifuged at $10,000 \times g$ to sediment the

155 cell debris, and the supernatant was used for subsequent immunoblotting experiments. For

156 HIF- $1 \alpha$ and HIF-1 $\beta$ determinations, $100 \mu \mathrm{g}$ of protein was fractionated by sodium dodecyl

157 sulfate-polyacrylamide gel electrophoresis ( $7.5 \%$ gel), transferred to membranes and

158 immunoblotted using primary antibodies at a dilution of 1:1,000. Horseradish peroxidase-

159 conjugated to sheep anti-mouse IgG (GE Healthcare, Piscataway, NJ) was used as a secondary

160 antibody at a dilution of 1:1,000. The signal was developed using enhanced

161 chemiluminescence reagent (GE Healthcare). Experiments were repeated at least two times and

162 the representative blots were demonstrated.

163 Measurement of [ATPi] 
164 MIN6 cells were plated in a 96-well tissue culture plate. After the indicated treatments, [ATPi]

165 was determined using a Cellno ATP Assay Kit (TOYO BNet), according to the manufacturer's

166 instructions. Briefly, $100 \mu \mathrm{l}$ of the lysis/assay solution provided by the manufacturer was added

167 to the cells. After shaking for $1 \mathrm{~min}$ and incubating for $10 \mathrm{~min}$ at $23^{\circ} \mathrm{C}$, the luminescence of an

168 aliquot of the solution was measured in a luminometer (ExSpire ${ }^{\mathrm{TM}}$, Perkin Emler, Waltham, MA)

169 (Koyanagi et al. 2011).

Quantitative reverse transcriptase-PCR analysis

RNA was purified using RNeasy ${ }^{\mathrm{TM}}$ (Qiagen, Valencia, CA) and treated with DNase. First-strand

synthesis and real-time PCR were performed using the QuantiTect SYBR green PCR kit

(Qiagen), according to the manufacturer's protocol. PCR primers were purchased from Qiagen.

PCR and detection were performed using a 7300 real-time PCR system (Applied Biosystems,

Foster City, CA). The relative change in expression of each target mRNA relative to 18S rRNA

was calculated (Suzuki et al. 2013). 
178 siRNAs corresponding to mouse HIF-1 $\alpha$ were from Qiagen Inc. MIN6 cells were transfected

179 by $100 \mathrm{nM}$ siRNA using HiPer-Fect ${ }^{\mathrm{TM}}$ Transfection Reagent (Qiagen Inc.) following a protocol

180 provided by the manufacturer (Oda et al. 2008).

181 Statistical analysis

182 All experiments were repeated on at least two occasions in triplicate. Data were expressed as

183 the mean \pm SD and analyzed by one-way analysis of variance, followed by Turkey's multiple

184 comparisons test. All statistical analyses were performed with EZR (Saitama Medical Center,

185 Jichi Medical University), which is a graphical user interface for R (The R Foundation for

186 Statistical Computing, version 3.1.3) (Kanda 2013). More precisely, it is a modified version of

187 R commander (version 1.6-3) and includes statistical functions that are frequently used in

188 biostatistics. A $P$-value of $<0.05$ was considered statistically significant. 


\section{Results}

Establishment of the GSIS experimental system in MIN6 cells

First, we investigated the insulin secretion response of MIN6 and MIN7 cells to stimulation by extracellular glucose. MIN6 and MIN7 cells were maintained with $40 \mathrm{mg} / \mathrm{dl}$ glucose and then exposed to a range of glucose concentrations $(40-400 \mathrm{mg} / \mathrm{dl})$ for $1 \mathrm{~h}$. Concentration-dependent GSIS was observed in response to 100-400 mg/dl glucose in MIN6 cells (Fig. 1A). GSIS was not observed in MIN7 cells (Fig. 1A) (Miyazaki et al. 1990). The time profile of the GSIS of MIN6 cells was also examined. The cells were exposed to medium containing $400 \mathrm{mg} / \mathrm{dl}$ glucose and the insulin concentrations were measured at 10, 20, 40, 60, and $120 \mathrm{~min}$ (Fig. 1B). Insulin secretion reached its maximum point at $40 \mathrm{~min}$. The insulin secretion response to the polysaccharides, sucrose and maltose, was investigated at molar concentrations corresponding to $400 \mathrm{mg} / \mathrm{dl}$ glucose (Fig. 1C). Insulin secretion was only observed in the presence of glucose in MIN6 cells.

Reversible inhibition of GSIS by isoflurane and sevoflurane 
203 We examined the effect of isoflurane and sevoflurane on GSIS in MIN6 cells. The cells were

204 incubated with the indicated dose of anesthetic and $400 \mathrm{mg} / \mathrm{dl}$ glucose for $1 \mathrm{~h}$ prior to

205 determination of the insulin concentrations of the culture supernatants. Isoflurane and

206 sevoflurane inhibited GSIS significantly in a concentration-dependent manner between $0.6 \%$ and

$2072.4 \%$ for isoflurane (Fig. 2A), and between $0.8 \%$ and $3.6 \%$ for sevoflurane (Fig. 2B).

208 To examine whether this suppression of GSIS was reversible, MIN6 cells were exposed to $1.2 \%$

209 isoflurane or $1.8 \%$ sevoflurane with $400 \mathrm{mg} / \mathrm{dl}$ glucose for $1 \mathrm{~h}$; they were then incubated under

$21040 \mathrm{mg} / \mathrm{dl}$ glucose without isoflurane or sevoflurane for $6 \mathrm{~h}$, prior to re-exposure to $400 \mathrm{mg} / \mathrm{dl}$

211 glucose. No statistically significant differences were observed in the GSIS of MIN6 cells

212 pretreated with volatile anesthetics and those that were not exposed to these compounds (Fig.

$2132 \mathrm{C})$.

214 The effect of volatile anesthetics on molecular aspects of GSIS in MIN6 cells

215 To investigate the molecular mechanisms underlying volatile anesthetic-mediated GSIS

216 inhibition, cell proliferation and cell death were examined in MIN6 cells. Exposure to these

217 volatile anesthetics (isoflurane: $2.4 \%$, sevoflurane: $3.6 \%$ ) for $8 \mathrm{~h}$ did not induce caspase $3 / 7$ 
218 activation in MIN6 cells (Fig. 3A) and 8-h exposure periods did not affect the cell proliferation

219 rate (Fig. 3B). This indicated that exposure to these volatile anesthetics did produce any

220 statistically significant effects on MIN6 cell death or proliferation.

221 The expression of proteins involved in GSIS was investigated. mRNA expression of the

222 glucose transporter 2 (GLUT2), the Kir6.2 subunit of $\mathrm{K}_{\mathrm{ATP}}$, and the voltage-dependent calcium

223 channel, Cav1.2, was not affected by glucose or by the volatile anesthetics within $1 \mathrm{~h}$ (Fig. 3C).

224 The effect of volatile anesthetics on intracellular signaling processes involved in GSIS

225 [ATPi] has been reported to increase in response to high-glucose stimulation in pancreatic $\beta$-cells

226 (Ashcroft 2005). We investigated the effect of isoflurane and sevoflurane over intracellular

227 ATP concentration at $40 \mathrm{~min}$ and $2 \mathrm{~h}$ after exposure to $400 \mathrm{mg} / \mathrm{dl}$ glucose. In MIN6 cells, the

228 mitochondrial electric transfer chain inhibitor, rotenone $(100 \mathrm{nM})$, suppressed the glucose-

229 induced increase in [ATPi]. Exposure to 2.4\% isoflurane or 3.6\% sevoflurane suppressed the

230 increase in [ATPi] observed in response to $400 \mathrm{mg} / \mathrm{dl}$ glucose stimulation at $40 \mathrm{~min}$ (Fig. 4A)

231 and $2 \mathrm{~h}$ (Fig. 4B). But the effects were weaker than 100nM rotenone, which suppressed GSIS

232 (Fig.4C). 
233 Elevation of [ATPi] closes $\mathrm{K}_{\mathrm{ATP}}$ and depolarizes the plasma membrane (Ashcroft 2005; Seino

234 2012). The channel opener, diazoxide, inhibited insulin secretion in pancreatic $\beta$-cells (Seino

235 2012), while channel blockade by glibenclamide facilitated insulin secretion, even under low-

236 glucose conditions. In MIN6 cells, glibenclamide induced insulin secretion in the presence of 400

$237 \mathrm{mg} / \mathrm{dl}$ glucose, but even with $40 \mathrm{mg} / \mathrm{dl}$ glucose; conversely, diazoxide suppressed GSIS observed in

238 the presence of $400 \mathrm{mg} / \mathrm{dl}$ glucose (Fig. 4D). Neither $2.4 \%$ isoflurane nor $3.6 \%$ sevoflurane

239 affected glibenclamide-induced insulin secretion (Fig. 4E).

240 The effects of volatile anesthetics on the OCR

241 The elevated mitochondrial respiration observed in response to high-glucose simulation

242 contributes to cellular hypoxia and HIF-1 activation in MIN6 cells (Kurokawa et al. 2015; Sato

243 et al. 2011). We found that exposure to high levels of glucose significantly increased the OCR

244 in MIN6 cells but to a lesser extent than the mitochondrial uncoupler, CCCP (5 $\mu \mathrm{M})($ Fig. 5).

245 The mitochondrial electron transfer chain inhibitor, rotenone $(100 \mathrm{nM})$, suppressed the OCR.

246 Importantly, 1.2\% isoflurane and 1.8\% sevoflurane also suppressed the OCR, although to a

247 lesser extent than rotenone. 
In order to elucidate the time course of HIF-1 activation, HIF-1 $\alpha$ protein accumulation was investigated. As early as $1 \mathrm{~h}$ after exposure to $400 \mathrm{mg} / \mathrm{dl}$ glucose, HIF-1 $\alpha$ protein accumulation was observed (Fig. 6A). Both of the tested volatile anesthetics significantly suppressed $\mu \mathrm{M})$ (Zhou et al. 2007) or nPG $(100 \mu \mathrm{M})$ (Kimura et al. 2008) increased HIF-1 $\alpha$ protein expression, which was not affected by isoflurane (Fig. 6C). The mRNA expression of HIF-1 $\alpha$ was not affected by exposure to a high glucose level, volatile anesthetics, DMOG, or n-PG. In contrast, expression of downstream genes such as the glucose transporter 1 (GLUT1) and vascular endothelial growth factor (VEGF) were suppressed by isoflurane treatment. Importantly, this suppression was not observed by pretreatment with DMOG or n-PG (Fig. 6D).

To elucidate the involvement of HIF-1 in glucose-elicited insulin secretion, effect of inhibition of 
263 siRNA (Fig. 7A) and induction of the expression of HIF-1 $\alpha$ protein was also suppressed by anti-

264 hif1 $\alpha$ siRNA (Fig.7B). YC-1 treatment did not affect the expression of mRNA and protein of

265 HIF-1 $\alpha$ subunit (Figs.7A and B).

266 Inhibition of HIF-1 activity by YC-1 treatment and RNA interference-mediated knockdown of

267 HIF-1 $\alpha$ expression significantly suppressed GSIS in MIN6 cells (Fig. 7C). To examine if the

268 constitutive activity of HIF-1 could rescue the suppression of GSIS by volatile anesthetics, MIN6

269 cells were incubated with $100 \mu \mathrm{M}$ DMOG or nPG for $8 \mathrm{~h}$ before treatment with the volatile

270 anesthetics. This inhibited HIF- $\alpha$ prolyl and asparaginyl hydroxylases, which induced HIF-1

271 activation, even under normoxic conditions. This pre-activation of HIF-1 inhibited the

272 isoflurane-mediated suppression of GSIS and reduction of [ATPi] (Figs. 7D and 7E). 


\section{Discussion}

This study demonstrated that the volatile anesthetics, isoflurane and sevoflurane, significantly suppressed GSIS in the mouse pancreatic $\beta$-cell-derived MIN6 cell line in clinically relevant doses. Our findings also indicated that these volatile anesthetics inhibited the glucose-induced increase in [ATPi] by suppressing HIF-1 activation in response to glucose-induced intracellular hypoxia. isoflurane or sevoflurane (Fig. 4E). In addition, we demonstrated that mRNA expression of GLUT2, Kir6.2, and Cav1.2 was not affected by isoflurane treatment (Fig. 3C). This evidence strongly suggests that the cellular processes involved in glucose intake or plasma membrane depolarization were not affected by these volatile anesthetics.

[ATPi] (Fig. 4A). This may be the most important mechanism underlying the GSIS inhibition induced by both of these anesthetics. HIF-1 $\alpha$ protein expression is controlled by the cellular 
289

290

291

292

293

oxygen tension (Hirota \& Semenza 2005), which is reduced by exposure of cells to high-glucose

conditions (Kurokawa et al. 2015; Sato et al. 2011). We previously reported that volatile

anesthetics, including halothane, isoflurane and sevoflurane, inhibited hypoxia-induced HIF

activation in vitro and in vivo (Itoh et al. 2001; Kai et al. 2014). Moreover, we demonstrated

that the volatile anesthetics partially attenuated glucose-induced oxygen consumption (Fig. 5).

This may be one of the mechanisms by which volatile anesthetics suppress glucose-induced HIF-

1 activation. Another novel finding of the present study was that glucose-induced ATP production

was partially dependent on HIF-1 activity; YC-1-mediated inhibition of HIF-1 significantly reduced

[ATPi] and GSIS (Figs. 7C). Moreover, DMOG- or nPG-induced pre-activation of HIF-1, which

was resistant to volatile anesthetic treatment, attenuated the effects of volatile anesthetics on

[ATPi] and GSIS induced by the volatile anesthetics (Figs. 7D and 7E). Our experimental results indicated that these volatile anesthetics also inhibited the increase in OCR (Fig. 5). In addition, glucose-induced the serine/threonine kinase AKT- and mammalian target of rapamycin (mTOR)dependent HIF- $1 \alpha$ signaling may partially contribute the HIF-1 activation observed in the present study (Harada et al. 2009; Oda et al. 2006). In a previous study, we reported that the volatile anesthetic halothane inhibited HIF-1 $\alpha$ accumulation elicited by exposure to hypoxia and 
desferrioxamine in Hep3B cells (Itoh et al. 2001). In this study, however, HIF-1 $\alpha$ accumulation by DMOG and nPG, which are identified as inhibitors of HIF-1 $\alpha$-hydroxylases, are resistant to isoflurane treatment (Fig. 6C) in MIN6 cells. The reasons of this discrepancy are unknown at this moment. But the differences between halothane and isoflurane and between Hep3B cells and MIN6 cells may partially explains the discrepancy.

Although the involvement of HIF-1 in GSIS in pancreatic $\beta$-cells remains controversial because the role of this transcription factor in these cells is not fully understood, there is some evidence that HIF-1 influences insulin secretion. Islets were reported to be exposed to relatively hypoxic conditions, even under normal conditions (Ashcroft 2005). Genetic ablation of HIF-1 $\alpha$ or HIF$1 \beta$ significantly inhibited GSIS in mice (Cheng et al. 2010; Gunton et al. 2005; Pillai et al. 2011), while a large experimental increase in HIF-1 $\alpha$ protein and HIF-1 activity levels caused by genetic ablation of the von Hippel Lindau (VHL) protein in mouse pancreatic $\beta$-cells attenuated GSIS and increased lactate levels (Cantley et al. 2009; Puri et al. 2009; Zehetner et al. 2008). However, less than $3 \%$ of patients with VHL syndrome, caused by a loss of VHL function, showed abnormal glucose tolerance (Ashcroft 2005). In addition, although mutations in subunits of the succinate dehydrogenase complex and in HIF-1 $\alpha$ prolyl hydroxylases are 
321

322

323

324

325

326

327

328

329

330

331

332

333

associated with HIF-1 hyperactivity, there are no reported changes in glucose tolerance (Ashcroft

2005). In HIF-1 $\alpha$-deficient mice, the hematopoietic stem cells (HSCs) lost their cell cycle

quiescence and HSC numbers decreased during various stressful conditions, including bone marrow transplantation and myelosuppression (Takubo et al. 2010). Conversely, increased HIF-1 $\alpha$ protein levels in response to biallelic loss of VHL induced cell cycle quiescence in HSCs and their progenitors but impaired transplantation capacity (Takubo et al. 2010). This indicated that the fine tuning of HIF-1 $\alpha$ protein expression and HIF-1 activity is critical in the regulation of biological responses. Moreover, the level of HIF-1 $\alpha$ protein expression influences insulin secretion; a mild increase of HIF-1 $\alpha$ protein level is beneficial for $\beta$-cell function, whereas overexpression of HIF-1 $\alpha$ protein, caused by VHL deletion or severe hypoxia, is deleterious for $\beta$-cell function (Ashcroft 2005). Although the GSIS process is very rapid and we did not provide the results on the detail of molecular process between HIF-1 transcriptional activity and maintenance of intracellular ATP concentration, our experimental results indicate the involvement of HIF-1 in the suppressive effect of the volatile anesthetics of GSIS. 


\section{Conclusion}

337 This study examined the effects of the volatile anesthetics, sevoflurane and isoflurane, on GSIS.

338 Both the anesthetics inhibited the glucose-induced increase of [ATPi], which is dependent on

339 intracellular hypoxia-induced HIF-1 activity, and suppressed GSIS at a clinically relevant dose in

340 MIN6 cells (Fig. 8). 


\section{Acknowledgements}

343 We would like to thank Dr. Hiroshi Harada at Kyoto University for critical reading of the

344 manuscript, Dr. Miyazaki at Osaka University for gifting MIN6 and MIN7 cells and Editage

345 (www.editage.jp) for English language editing. 
References

Ashcroft FM. 2005. ATP-sensitive potassium channelopathies: focus on insulin secretion. J Clin

Invest 115:2047-2058.

Bensellam M, Duvillie B, Rybachuk G, Laybutt DR, Magnan C, Guiot Y, Pouyssegur J,

Jonas JC. 2012. Glucose-induced $\mathrm{O}(2)$ consumption activates hypoxia inducible factors 1 and 2

in rat insulin-secreting pancreatic beta-cells. PLoS One 7:e29807.

Cantley J, Selman C, Shukla D, Abramov AY, Forstreuter F, Esteban MA, Claret M,

Lingard SJ, Clements M, Harten SK, Asare-Anane H, Batterham RL, Herrera PL,

Persaud SJ, Duchen MR, Maxwell PH, Withers DJ. 2009. Deletion of the von Hippel-Lindau

gene in pancreatic beta cells impairs glucose homeostasis in mice. J Clin Invest 119:125-135.

Cheng K, Ho K, Stokes R, Scott C, Lau SM, Hawthorne WJ, O'Connell PJ, Loudovaris T,

Kay TW, Kulkarni RN, Okada T, Wang XL, Yim SH, Shah Y, Grey ST, Biankin AV,

Kench JG, Laybutt DR, Gonzalez FJ, Kahn CR, Gunton JE. 2010. Hypoxia-inducible factor- 
Goto Y, Zeng L, Yeom CJ, Zhu Y, Morinibu A, Shinomiya K, Kobayashi M, Hirota K, Itasaka S, Yoshimura M, Tanimoto K, Torii M, Sowa T, Menju T, Sonobe M, Kakeya H, Toi M, Date H, Hammond EM, Hiraoka M, Harada H. 2015. UCHL1 provides diagnostic and antimetastatic strategies due to its deubiquitinating effect on HIF-1alpha. Nature communications 6:6153.

\section{Gunton JE, Kulkarni RN, Yim S, Okada T, Hawthorne WJ, Tseng YH, Roberson RS,} Ricordi C, O'Connell PJ, Gonzalez FJ, Kahn CR. 2005. Loss of ARNT/HIF1beta mediates altered gene expression and pancreatic-islet dysfunction in human type 2 diabetes. Cell 122:337349.

Harada H, Itasaka S, Kizaka-Kondoh S, Shibuya K, Morinibu A, Shinomiya K, Hiraoka M.

2009. The Akt/mTOR pathway assures the synthesis of HIF-1alpha protein in a glucose- and reoxygenation-dependent manner in irradiated tumors. J Biol Chem 284:5332-5342.

Hirota K, Semenza GL. 2005. Regulation of hypoxia-inducible factor 1 by prolyl and asparaginyl hydroxylases. Biochem Biophys Res Commun 338:610-616.

Itoh T, Namba T, Fukuda K, Semenza GL, Hirota K. 2001. Reversible inhibition of hypoxiainducible factor 1 activation by exposure of hypoxic cells to the volatile anesthetic halothane. 
377

378

379

FEBS Lett 509:225-229.

\section{Kai S, Tanaka T, Daijo H, Harada H, Kishimoto S, Suzuki K, Takabuchi S, Takenaga K,}

Fukuda K, Hirota K. 2012. Hydrogen sulfide inhibits hypoxia- but not anoxia-induced

hypoxia-inducible factor 1 activation in a von hippel-lindau- and mitochondria-dependent

manner. Antioxid Redox Signal 16:203-216.

Kai S, Tanaka T, Matsuyama T, Suzuki K, Hirota K. 2014. The volatile anesthetic isoflurane

differentially suppresses the induction of erythropoietin synthesis elicited by acute anemia and systemic hypoxemia in mice in an hypoxia-inducible factor-2-dependent manner. Eur J

Pharmacol 732C:43-49.

Kanda Y. 2013. Investigation of the freely available easy-to-use software 'EZR' for medical statistics. Bone Marrow Transplant 48:452-458.

\section{Kimura M, Takabuchi S, Tanaka T, Murata M, Nishi K, Oda S, Oda T, Kanai M, Fukuda}

K, Kizaka-Kondoh S, Adachi T, Takabayashi A, Semenza GL, Hirota K. 2008. n-Propyl gallate activates hypoxia-inducible factor 1 by modulating intracellular oxygen-sensing systems.

Biochem J 411:97-105.

Koyanagi M, Asahara S, Matsuda T, Hashimoto N, Shigeyama Y, Shibutani Y, Kanno A, 
393

394

395

396

Fuchita M, Mikami T, Hosooka T, Inoue H, Matsumoto M, Koike M, Uchiyama Y, Noda T,

Seino S, Kasuga M, Kido Y. 2011. Ablation of TSC2 enhances insulin secretion by increasing the number of mitochondria through activation of mTORC1. PLoS One 6:e23238.

\section{Kurokawa H, Ito H, Inoue M, Tabata K, Sato Y, Yamagata K, Kizaka-Kondoh S,}

Kadonosono T, Yano S, Inoue M, Kamachi T. 2015. High resolution imaging of intracellular

oxygen concentration by phosphorescence lifetime. Sci Rep 5:10657.

Kwon S, Thompson R, Dellinger P, Yanez D, Farrohki E, Flum D. 2013. Importance of

perioperative glycemic control in general surgery: a report from the Surgical Care and Outcomes

Assessment Program. Ann Surg 257:8-14.

Lipshutz AK, Gropper MA. 2009. Perioperative glycemic control: an evidence-based review.

Anesthesiology 110:408-421.

Martinez EA, Williams KA, Pronovost PJ. 2007. Thinking like a pancreas: perioperative glycemic control. Anesth Analg 104:4-6.

Matsumoto T, Sakurai K, Tanaka A, Ishibashi T, Tachibana K, Ishikawa K, Yokote K.

2012. The anti-ulcer agent, irsogladine, increases insulin secretion by MIN6 cells. Eur J

Pharmacol 685:213-217. 
409

410

411

412

413

414

415

416

417

Miyazaki J, Araki K, Yamato E, Ikegami H, Asano T, Shibasaki Y, Oka Y, Yamamura K.

1990. Establishment of a pancreatic beta cell line that retains glucose-inducible insulin secretion:

special reference to expression of glucose transporter isoforms. Endocrinology 127:126-132.

Namba T, Ishii TM, Ikeda M, Hisano T, Itoh T, Hirota K, Adelman JP, Fukuda K. 2000.

Inhibition of the human intermediate conductance $\mathrm{Ca}(2+)$-activated $\mathrm{K}(+)$ channel, hIK1, by

volatile anesthetics. Eur J Pharmacol 395:95-101.

\section{Oda S, Oda T, Nishi K, Takabuchi S, Wakamatsu T, Tanaka T, Adachi T, Fukuda K,}

Semenza GL, Hirota K. 2008. Macrophage migration inhibitory factor activates hypoxiainducible factor in a p53-dependent manner. PLoS One 3:e2215.

Oda T, Hirota K, Nishi K, Takabuchi S, Oda S, Yamada H, Arai T, Fukuda K, Kita T, Adachi T, Semenza GL, Nohara R. 2006. Activation of hypoxia-inducible factor 1 during macrophage differentiation. Am J Physiol Cell Physiol 291:C104-C113.

\section{Pillai R, Huypens P, Huang M, Schaefer S, Sheinin T, Wettig SD, Joseph JW. 2011. Aryl}

hydrocarbon receptor nuclear translocator/hypoxia-inducible factor-1 \{beta\} plays a critical role in maintaining glucose-stimulated anaplerosis and insulin release from pancreatic $\{$ beta $\}$-cells. $\mathrm{J}$ 
425 Puri S, Cano DA, Hebrok M. 2009. A role for von Hippel-Lindau protein in pancreatic beta-

426 cell function. Diabetes 58:433-441.

427 Rorsman P. 1997. The pancreatic beta-cell as a fuel sensor: an electrophysiologist's viewpoint.

428 Diabetologia 40:487-495.

429

430

431

432

\section{Sato Y, Endo H, Okuyama H, Takeda T, Iwahashi H, Imagawa A, Yamagata K,}

Shimomura I, Inoue M. 2011. Cellular hypoxia of pancreatic beta-cells due to high levels of oxygen consumption for insulin secretion in vitro. J Biol Chem 286:12524-12532.

Seino S. 2012. Cell signalling in insulin secretion: the molecular targets of ATP, cAMP and sulfonylurea. Diabetologia 55:2096-2108.

\section{Suzuki K, Nishi K, Takabuchi S, Kai S, Matsuyama T, Kurosawa S, Adachi T, Maruyama}

T, Fukuda K, Hirota K. 2013. Differential roles of prostaglandin E-type receptors in activation of hypoxia-inducible factor 1 by prostaglandin E1 in vascular-derived cells under non-hypoxic conditions. PeerJ 1:e220.

\section{Takubo K, Goda N, Yamada W, Iriuchishima H, Ikeda E, Kubota Y, Shima H, Johnson RS,}

Hirao A, Suematsu M, Suda T. 2010. Regulation of the HIF-1alpha level is essential for

hematopoietic stem cells. Cell Stem Cell 7:391-402. 
441 Tanaka K, Kawano T, Tomino T, Kawano H, Okada T, Oshita S, Takahashi A, Nakaya Y.

442 2009. Mechanisms of impaired glucose tolerance and insulin secretion during isoflurane

443 anesthesia. Anesthesiology 111:1044-1051.

444 Tanaka K, Kawano T, Tsutsumi YM, Kinoshita M, Kakuta N, Hirose K, Kimura M,

445 Oshita S. 2011a. Differential effects of propofol and isoflurane on glucose utilization and insulin

446 secretion. Life Sci 88:96-103.

447 Tanaka T, Kai S, Koyama T, Daijo H, Adachi T, Fukuda K, Hirota K. 2011b. General

448 Anesthetics Inhibit Erythropoietin Induction under Hypoxic Conditions in the Mouse Brain.

449 PLoS One 6:e29378.

Tanaka T, Wakamatsu T, Daijo H, Oda S, Kai S, Adachi T, Kizaka-Kondoh S, Fukuda K,

Hirota K. 2010. Persisting mild hypothermia suppresses hypoxia-inducible factor-1alpha protein

Comp Physiol 298:R661-671.

Zehetner J, Danzer C, Collins S, Eckhardt K, Gerber PA, Ballschmieter P, Galvanovskis J,

glucose metabolism and insulin secretion in pancreatic beta cells. Genes Dev 22:3135-3146. 
457 Zhang H, Gao P, Fukuda R, Kumar G, Krishnamachary B, Zeller KI, Dang CV, Semenza

458 GL. 2007. HIF-1 inhibits mitochondrial biogenesis and cellular respiration in VHL-deficient

459 renal cell carcinoma by repression of C-MYC activity. Cancer Cell 11:407-420.

Zhou J, Hara K, Inoue M, Hamada S, Yasuda H, Moriyama H, Endo H, Hirota K,

availability under hypoxic conditions. Kobe J Med Sci 53:283-296. 

MIN7 cells were stimulated with the indicated glucose concentrations for $1 \mathrm{~h}$ and insulin secretion was determined as the difference between the medium insulin concentration before and after 8); ${ }^{*} P<0.05$, as compared with the control (A: glucose $40 \mathrm{mg} / \mathrm{dl}$, B: time $0 \mathrm{~min}$ ); $\# P<0.05$ for comparison of the indicated groups. 
479 sevoflurane for $1 \mathrm{~h}$, then incubated with $40 \mathrm{mg} / \mathrm{dl}$ glucose without isoflurane or sevoflurane for 6

$480 \mathrm{~h}$, and then exposed to $400 \mathrm{mg} / \mathrm{dl}$ glucose conditions for $1 \mathrm{~h}$ prior to calculation of insulin

481 secretion. Data are presented as the mean $\pm \mathrm{SD}(\mathrm{A}$ and $\mathrm{B}: \mathrm{N}=3, \mathrm{n}=10, \mathrm{C}: \mathrm{N}=2, \mathrm{n}=6) ; \# P<0.05$

482 for comparison of the indicated groups. N: number of independent experiments performed, n:

483 number of samples

\section{Figure 3: The effect of volatile anesthetics on molecular aspects of GSIS in MIN6 cells}

MIN6 cells were exposed to the indicated concentration of glucose and isoflurane (iso) or

sevoflurane (sev) for $8 \mathrm{~h}$. A. Caspase 3/7 activity was assayed by the Apo-ONE ${ }^{\mathrm{TM}}$

Cell proliferation was assayed by colorimetric CellTiter 96 ${ }^{\mathrm{TM}}$ AQueous One Solution Cell

Proliferation Assay (Promega Corporation; Madison, WI) as described in Materials and Methods section; this contains 3-(4,5-dimethylthiazol-2-yl)-5-(3-carboxymethoxyphenyl)-2-(4-

sulfophenyl)-2H-tetrazolium, inner salt, and an electron coupling reagent (phenazine ethosulfate).

C. Cells were harvested and the mRNA levels of GLUT2, Cav1.2, and Kir6.2 were assayed by 
494 semi-quantitative reverse transcription real-time PCR. Data are presented as the mean \pm SD (n

$495=3)$.

GSIS A and B. MIN6 cells were exposed to the indicated levels of glucose with rotenone (rot),

ATP concentration, as described in the Materials and methods section. C and D. MIN6 cells 
509 Figure 5: The effects of volatile anesthetics on the OCR The oxygen consumption rate

510 (OCR) of MIN6 cells was assayed under the indicated conditions, as described in the Materials

511 and methods section. OCR was expressed as the ratio to that observed in MIN6 cells exposed

512 to $40 \mathrm{mg} / \mathrm{d}$ glucose. Data are presented as the mean $\pm \mathrm{SD}(\mathrm{n}=3) * P<0.05$, as compared with

513 the control; $\# P<0.05$ for comparison of the indicated groups. iso: isoflurane; sev: sevoflurane;

514 rot: rotenone; CCCP: carbonyl cyanide m-chlorophenylhydrazone.

516 Figure 6: The effects of volatile anesthetics on HIF-1 in GSIS A, B and C. These cells had

517 been exposed to the indicated glucose levels, with or without isoflurane (iso) (B) or sevoflurane

518 (sev) (B), or with dimethyloxaloylglycine (DMOG) or 3,4,5-trihydroxybenzoic acid propyl ester

519 (n-PG), with or without isoflurane (C) under $20 \% \mathrm{O}_{2}$ conditions for $4 \mathrm{~h}$. MIN6 whole-cell

520 lysates were immunoblotted (IB) twice to detect HIF-1 $\alpha$ and HIF-1 $\beta$ proteins and representative

521 images are shown. D. Cells were harvested for semi-quantitative real-time PCR for HIF-1 $\alpha$,

522 glucose transporter 1 (GLUT1), and vascular endothelial growth factor (VEGF). Cell cultures

523 were repeated at least twice and the PCR analyses were performed in triplicate. Data are

524 presented as the fold induction, relative to the level observed with $40 \mathrm{mg} / \mathrm{dl}$ glucose and no drug 
525 treatment. Data are presented as the mean $\pm \mathrm{SD}(\mathrm{n}=3) ; \# P<0.05$ for comparison of the

526 indicated groups.

528 Figure 7: Impact of HIF-1 inhibition on GSIS A and B. MIN6 cells were transfected by

529100 nM siRNA using HiPer-Fect ${ }^{\text {TM }}$ Transfection Reagent (Qiagen Inc.) or treated with YC-1.

530 Cells were harvested for semi-quantitative real-time PCR for HIF-1 $\alpha(\mathrm{A})$. Cells were harvested

531 and whole-cell lysates were immunoblotted (IB) to detect HIF-1 $\alpha$ and HIF-1 $\beta$ proteins (B). C

532 and D. MIN6 cells were incubated with the indicated glucose concentrations for $1 \mathrm{~h}$, with or without

533 the indicated compounds, prior to determination of insulin secretion. Data are presented as the

534 mean $\pm \mathrm{SD}(\mathrm{N}=2, \mathrm{n}=6) ; \# P<0.05$ for comparison of the indicated groups. E. MIN6 cells were

535 exposed to the indicated glucose concentrations and compounds for $2 \mathrm{~h}$ prior to analysis of the

536 cellular ATP concentration, as described in the Materials and methods section. YC-1: 5-[1-

537 (phenylmethyl)-1H-indazol-3-yl]-2-furanmethanol. Data are presented as the mean $\pm \mathrm{SD}$; \#P<

5380.05 for comparison of the indicated groups. N: number of independent experiments performed,

539 n: number of samples 
541 Figure 8: A schematic diagram indicating the mechanism of GSIS suppression by volatile

542 anesthetics A. When the extracellular glucose concentration increases, pancreatic $\beta$-cell

543 metabolism accelerates, leading to an increase in [ATPi]. As a result of these metabolic

544 changes, the activity of ATP-dependent potassium channels $\left(\mathrm{K}_{\mathrm{ATP}}\right)$ decreases; this causes

545 membrane depolarization to the threshold potential at which voltage-dependent calcium channels

546 open, allowing $\mathrm{Ca}^{2+}$ influx. The ensuing increase in cytosolic $\mathrm{Ca}^{2+}$ concentration triggers

547 exocytosis of insulin-containing vesicles. B. Glucose-induced oxygen consumption is partially

548 suppressed by the volatile anesthetics (isoflurane and sevoflurane). Mitochondrial oxygen

549 consumption leads to cellular hypoxia, which activates HIF-1. The process is also inhibited by

550 volatile anesthetics. The glucose-induced increase in the intracellular ATP level is inhibited by

551 volatile anesthetics. Consequently, these compounds suppress GSIS, which is largely

552 dependent on the intracellular ATP concentration. 


\section{1}

Establishment of the GSIS experimental system in MIN6 cells

Figure 1: Establishment of the GSIS experimental system in MIN6 cells A. MIN6 and MIN7 cells were stimulated with the indicated glucose concentrations for $1 \mathrm{~h}$ and insulin secretion was determined as the difference between the medium insulin concentration before and after stimulation, as described in the Materials and methods section. B. MIN6 cells were incubated with $400 \mathrm{mg} / \mathrm{dl}$ glucose for the indicated times prior to calculation of insulin secretion. C. MIN6 cells were stimulated by $400 \mathrm{mg} / \mathrm{dl}(20 \mathrm{mM})$ glucose (glc), $20 \mathrm{mM}$ sucrose (suc), or $20 \mathrm{mM}$ maltose (mal) for $1 \mathrm{~h}$ prior to calculation of insulin secretion. Data are presented as the mean $\pm S D(N=3, n=8) ; * P<0.05$, as compared with the control (A: glucose $40 \mathrm{mg} / \mathrm{dl}$, B: time $0 \mathrm{~min}$ ); \#P<0.05 for comparison of the indicated groups.

A

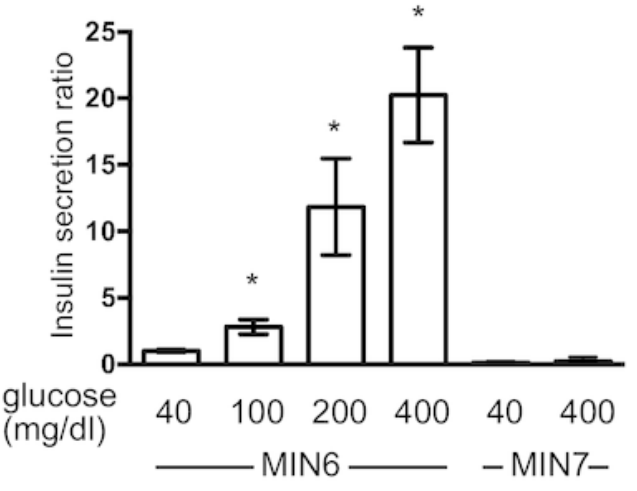

B

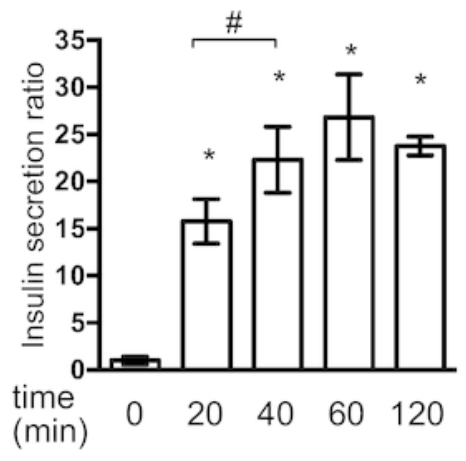

C

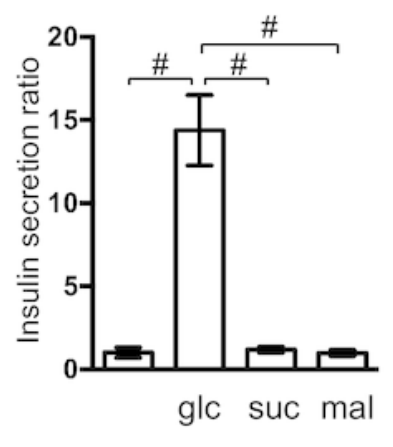




\section{2}

Reversible inhibition of GSIS by isoflurane and sevoflurane

Figure 2: Reversible inhibition of GSIS by isoflurane and sevoflurane MIN6 cells were stimulated with the indicated glucose concentrations for $1 \mathrm{~h}$, with or without the indicated dose of isoflurane (iso; A) or sevoflurane (sev; B), prior to calculation of insulin secretion. C. MIN6 cells were exposed to $400 \mathrm{mg} / \mathrm{dl}$ glucose and the indicated concentrations of isoflurane or sevoflurane for $1 \mathrm{~h}$, then incubated with $40 \mathrm{mg} / \mathrm{dl}$ glucose without isoflurane or sevoflurane for $6 \mathrm{~h}$, and then exposed to $400 \mathrm{mg} / \mathrm{dl}$ glucose conditions for $1 \mathrm{~h}$ prior to calculation of insulin secretion. Data are presented as the mean $\pm S D(A$ and $B: N=3, n=10$, $\mathrm{C}: \mathrm{N}=2, \mathrm{n}=6) ; \# P<0.05$ for comparison of the indicated groups. $\mathrm{N}$ : number of independent experiments performed, $\mathrm{n}$ : number of samples

A

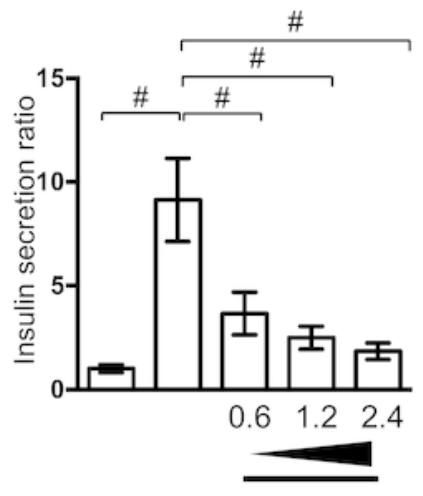

glucose $(\mathrm{mg} / \mathrm{dl})$
B

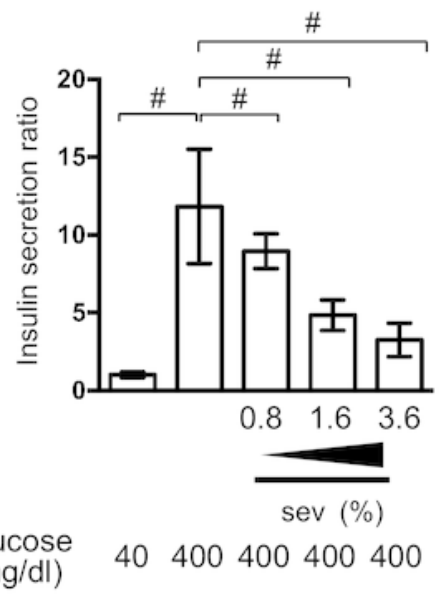

C

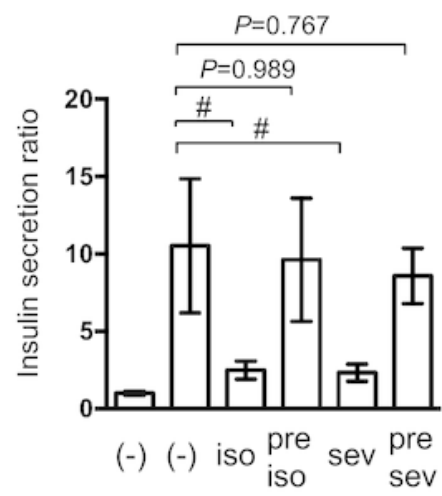

glucose $(\mathrm{mg} / \mathrm{dl})$ 


\section{3}

The effect of volatile anesthetics on molecular aspects of GSIS in MIN6 cells

Figure 3: The effect of volatile anesthetics on molecular aspects of GSIS in MIN6

cells MIN6 cells were exposed to the indicated concentration of glucose and isoflurane (iso) or sevoflurane (sev) for $8 \mathrm{~h}$. A. Caspase 3/7 activity was assayed by the Apo-ONE ${ }^{\mathrm{TM}}$ Homogeneous Caspase-3/7 Assay (Promega) as described in Materials and Methods section. B. Cell proliferation was assayed by colorimetric CellTiter $96^{\mathrm{Tm}}$ AQueous One Solution Cell Proliferation Assay (Promega Corporation; Madison, WI) as described in Materials and Methods section; this contains 3-(4,5-dimethylthiazol-2-yl)-5-(3-carboxymethoxyphenyl)-2-(4sulfophenyl)-2H-tetrazolium, inner salt, and an electron coupling reagent (phenazine ethosulfate). C. Cells were harvested and the mRNA levels of GLUT2, Cav1.2, and Kir6.2 were assayed by semi-quantitative reverse transcription real-time PCR. Data are presented as the mean $\pm S D(n=3)$. 
A

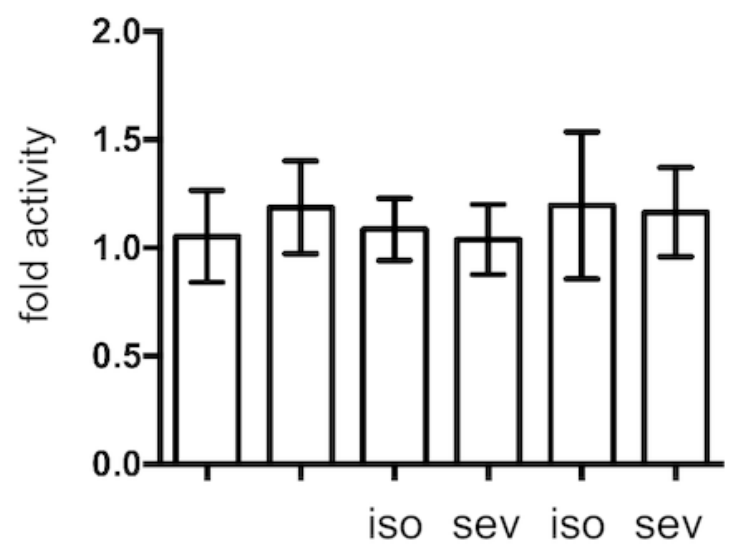

B

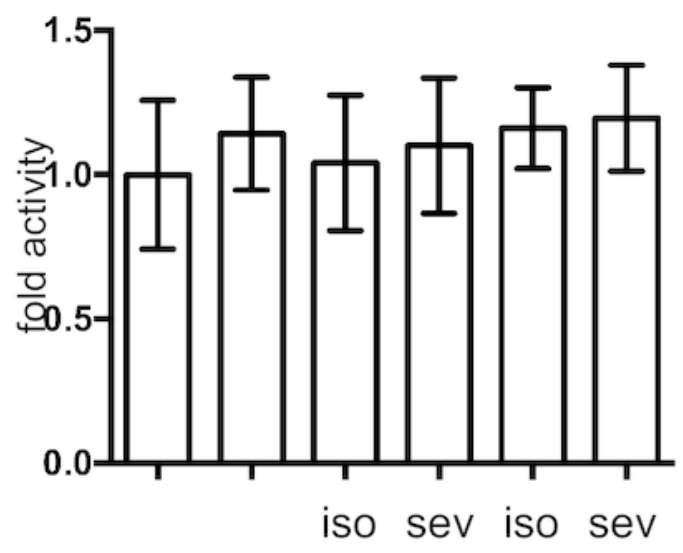

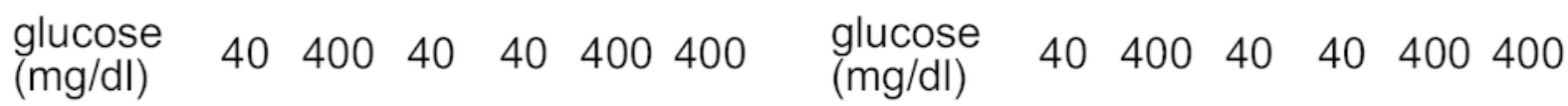

C

GLUT2

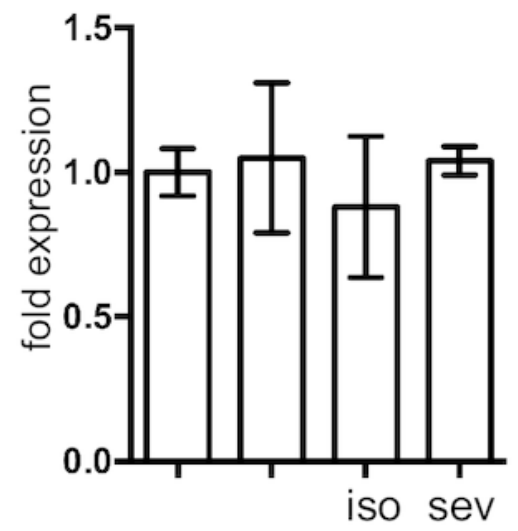

glucose (mg/dl)
40400400400

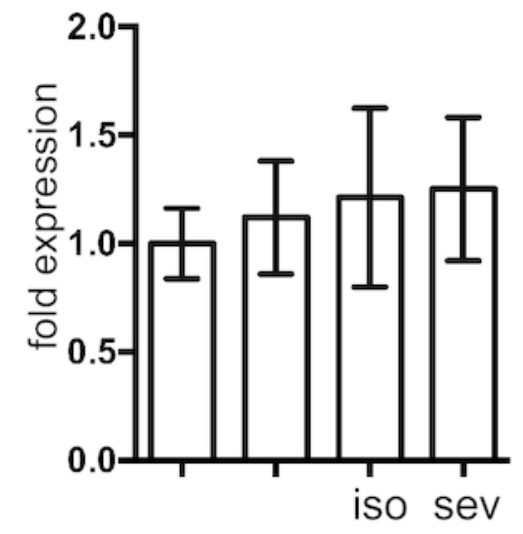

glucose
$(\mathrm{mg} / \mathrm{dl})$
Kir6.2

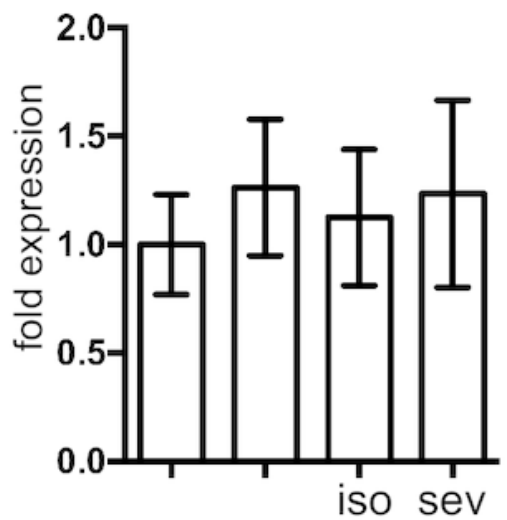
$40400400400 \begin{aligned} & \text { glucose } \\ & \text { (mg/dl) }\end{aligned} 40400400400$ 


\section{4}

The effect of volatile anesthetics on intracellular signaling processes involved in GSIS

Figure 4: The effect of volatile anesthetics on intracellular signaling processes

involved in GSIS A. MIN6 cells were exposed to the indicated levels of glucose with

rotenone (rot), $2.4 \%$ isoflurane (iso), or $3.6 \%$ sevoflurane (sev) for $2 \mathrm{~h}$ prior to analysis of the cellular ATP concentration, as described in the Materials and methods section. C and D. MIN6 cells were exposed to the indicated levels of glucose with rotenone (C), diazoxide (diaz; D), or glibenclamide (glib; D) for $1 \mathrm{~h}$ prior to insulin determination. D. MIN6 cells were exposed to $400 \mathrm{mg} / \mathrm{dl}$ glucose and glibenclamide with $1.8 \%$ isoflurane for $1 \mathrm{~h}$ prior to insulin determination. Data are presented as the mean $\pm S D(A$ and $B: N=2, n=6, C: N=1, n=3, C$ and $\mathrm{D}: \mathrm{N}=2, \mathrm{n}=6) ; * P<0.05$ as compared with the control (no glibenclamide treatment); $\# P<0.05$ for comparison of the indicated groups. $\mathrm{N}$ : number of independent experiments performed, n: number of samples 
A

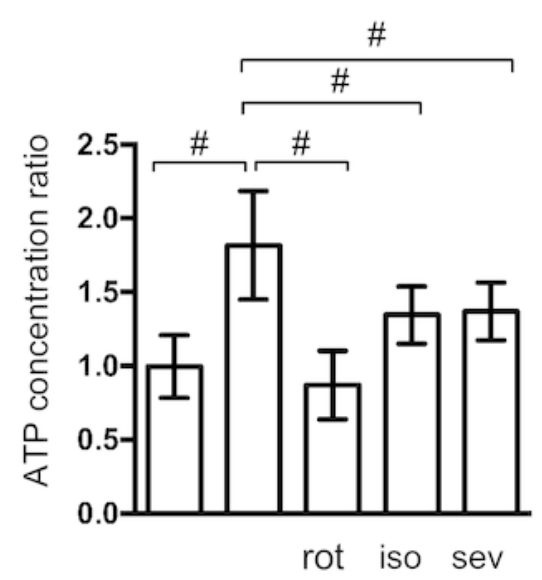

glucose $40 \quad 400400400400$

(mg/dl) 40400400400400
B

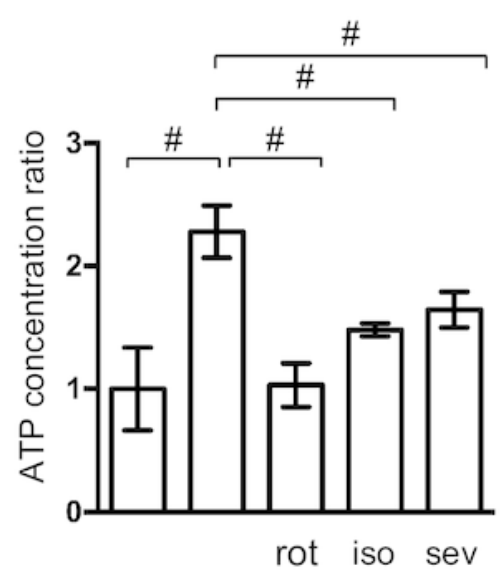

glucose

(mg/dl)
C

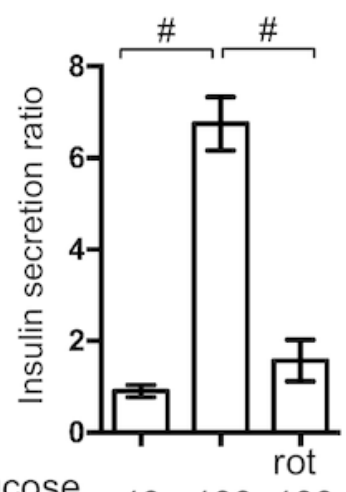

glucose (mg/dl)
D

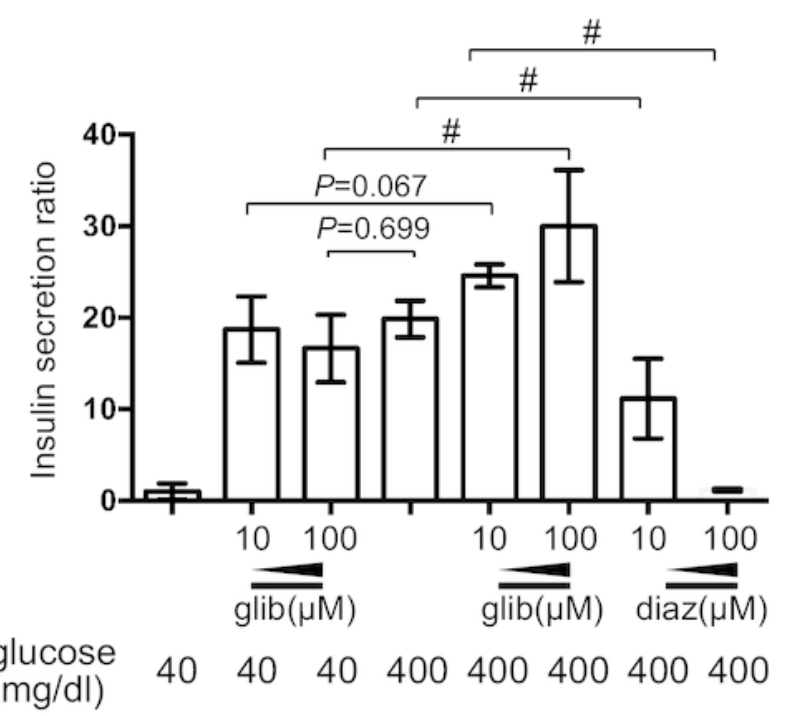

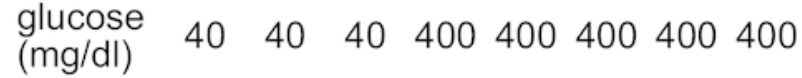

E $\quad \underbrace{P=0.565}_{*}$

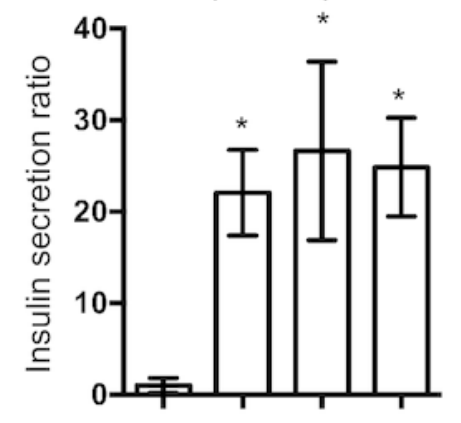

$\begin{array}{lllll}\text { glucose } & 40 & 40 & 40 & 40\end{array}$ 
5

The effects of volatile anesthetics on the OCR

Figure 5: The effects of volatile anesthetics on the OCR The oxygen consumption rate (OCR) of MIN6 cells was assayed under the indicated conditions, as described in the Materials and methods section. OCR was expressed as the ratio to that observed in MIN6 cells exposed to $40 \mathrm{mg} / \mathrm{dl}$ glucose. Data are presented as the mean $\pm \mathrm{SD}(\mathrm{n}=3) * P<0.05$, as compared with the control; $\# P<0.05$ for comparison of the indicated groups. iso: isoflurane; sev: sevoflurane; rot: rotenone; CCCP: carbonyl cyanide m-chlorophenylhydrazone.

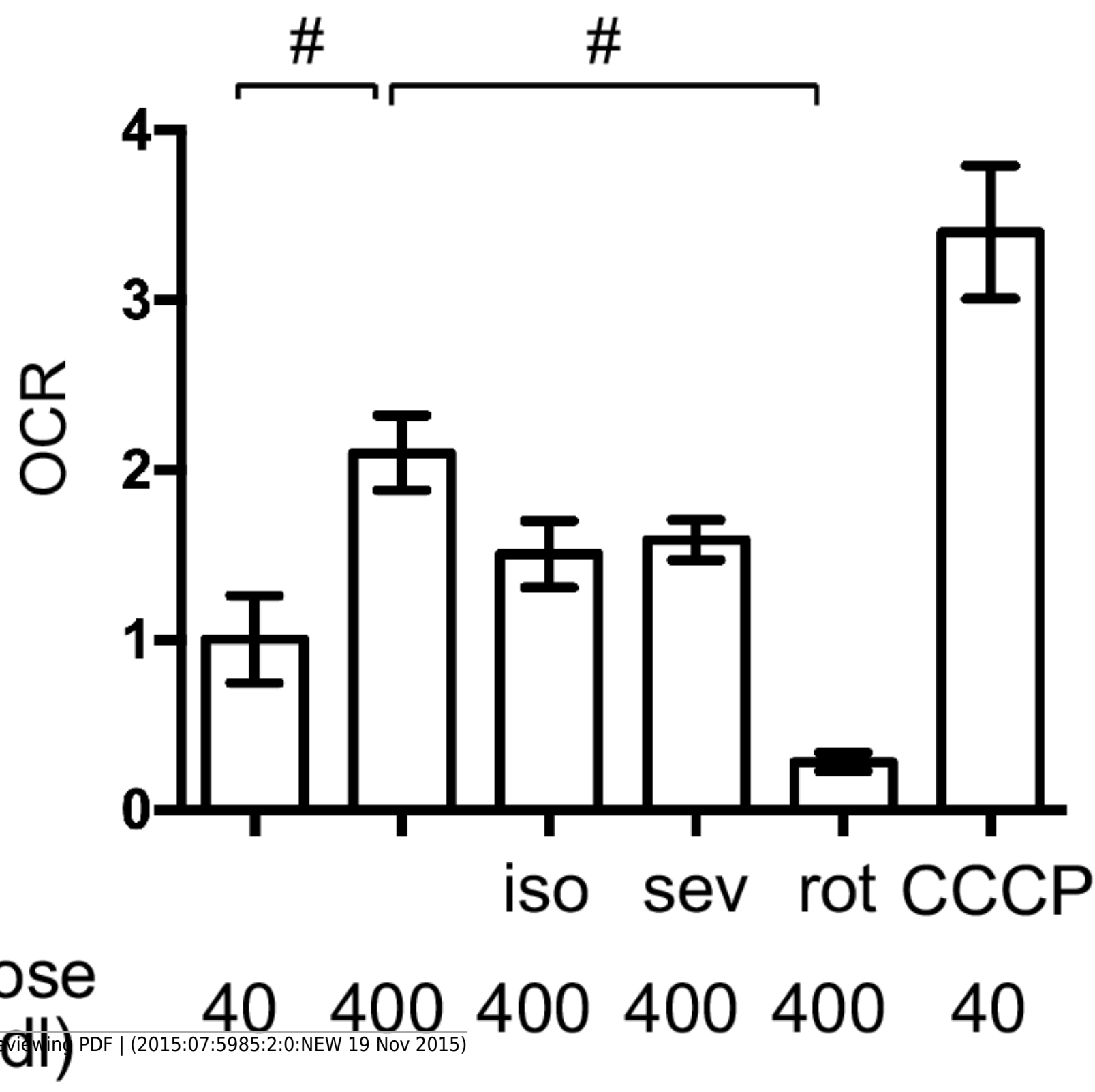




\section{6}

The effects of volatile anesthetics on HIF-1 in GSIS

Figure 6: The effects of volatile anesthetics on HIF-1 in GSIS A and B. MIN6 whole-cell lysates were immunoblotted (IB) twice to detect HIF-1 $\alpha$ and HIF-1 $\beta$ proteins and representative images are shown. These cells had been exposed to the indicated glucose levels, with or without isoflurane (iso) or sevoflurane (sev) (A), or with dimethyloxaloylglycine (DMOG) or 3,4,5-trihydroxybenzoic acid propyl ester (n-PG), with or without isoflurane (B) with $20 \% \mathrm{O}_{2}$ for $4 \mathrm{~h}$. C. Cells were harvested for semi-quantitative real-time PCR for HIF-1 $\alpha$, glucose transporter 1 (GLUT1), and vascular endothelial growth factor (VEGF). Cell cultures were repeated at least twice and the PCR analyses were performed in triplicate. Data are presented as the fold induction, relative to the level observed with $40 \mathrm{mg} / \mathrm{dl}$ glucose and no drug treatment. Data are presented as the mean $\pm S D(n=3)$; \#P<0.05 for comparison of the indicated groups.

A

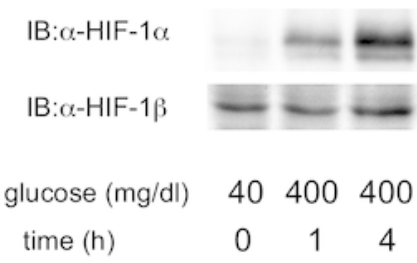

D

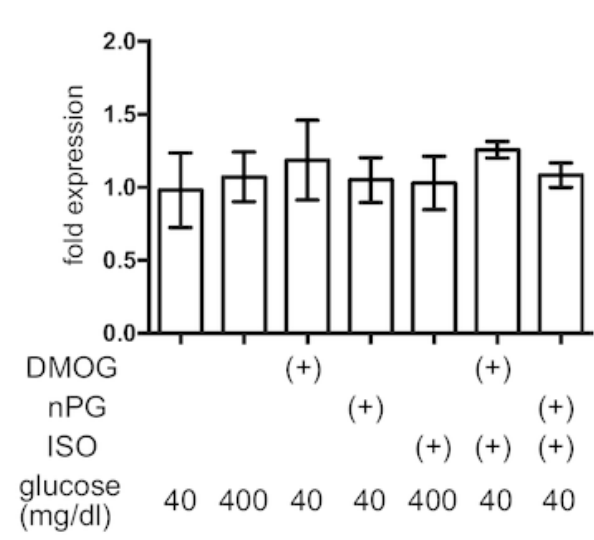

B

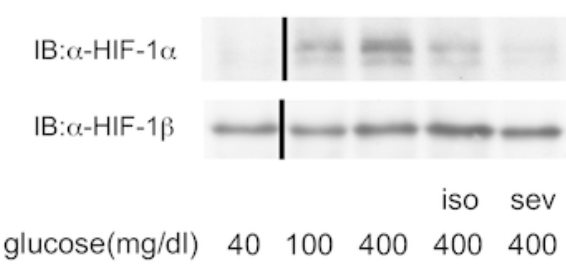

GLUT1
C

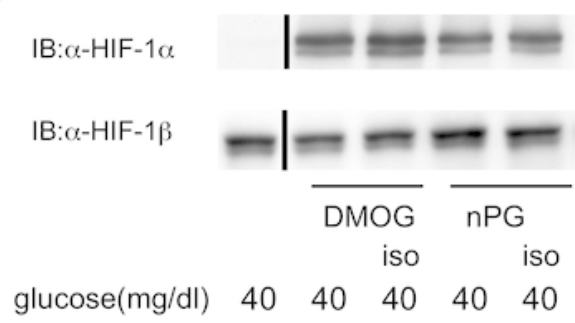

VEGF

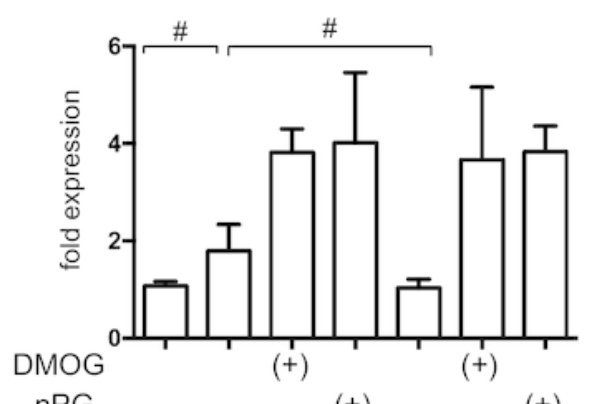

$(+)$

$(+) \quad(+) \quad(+)$ glucose (mg/dl) $\begin{array}{lllllll}40 & 400 & 40 & 40 & 400 & 40 & 40\end{array}$
ISG glucose (mg/dl)

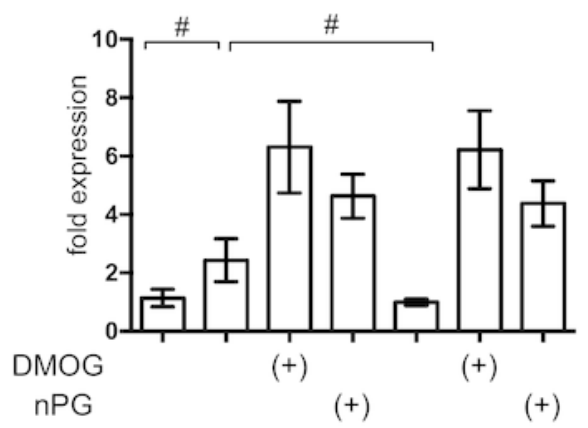

$(+) \quad(+) \quad(+)$

$\begin{array}{lllllll}40 & 400 & 40 & 40 & 400 & 40 \quad 40\end{array}$ 


\section{7}

Impact of HIF-1 inhibition on GSIS

Figure 7: Impact of HIF-1 inhibition on GSIS A and B. MIN6 cells were transfected by 100 nM siRNA using HiPer-Fect ${ }^{\text {TM }}$ Transfection Reagent (Qiagen Inc.) or treated with YC-1. Cells were harvested for semi-quantitative real-time PCR for HIF-1 $\alpha$ (A). Cells were harvested and whole-cell lysates were immunoblotted (IB) to detect HIF-1 $\alpha$ and HIF-1 $\beta$ proteins (B). C and D. MIN6 cells were incubated with the indicated glucose concentrations for $1 \mathrm{~h}$, with or without the indicated compounds, prior to determination of insulin secretion. Data are presented as the mean $\pm \mathrm{SD}(\mathrm{N}=2, \mathrm{n}=6) ; \# P<0.05$ for comparison of the indicated groups. E. MIN6 cells were exposed to the indicated glucose concentrations and compounds for $2 \mathrm{~h}$ prior to analysis of the cellular ATP concentration, as described in the Materials and methods section. YC-1: 5-[1-(phenylmethyl)-1H-indazol-3-yl]-2-furanmethanol. Data are presented as the mean $\pm \mathrm{SD} ; \# P<0.05$ for comparison of the indicated groups. $\mathrm{N}$ : number of independent experiments performed, $n$ : number of samples 


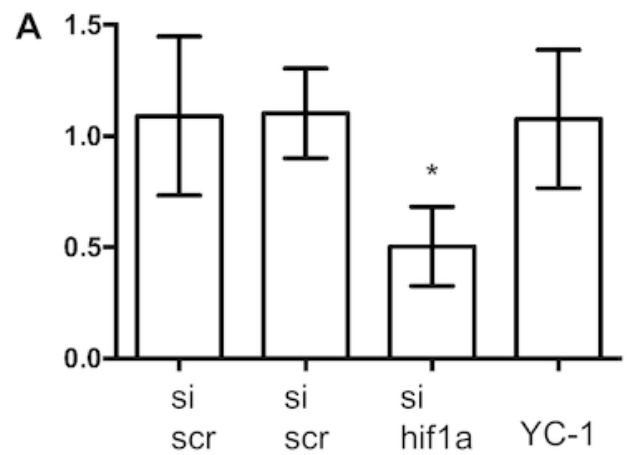

B

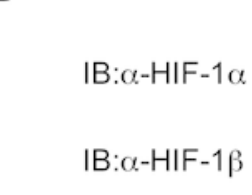

$\begin{array}{llll}\text { si } & \text { si } & \text { si } & \text { YC-1 } \\ \text { scr } & \text { scr } & \text { hif1a } & \end{array}$

glucose (mg/dl) $40 \quad 400400 \quad 400$

$\begin{array}{lllll}\begin{array}{l}\text { glucose } \\ \text { (mg/dl) }\end{array} & 400 & 400 & 400 & 400\end{array}$

C

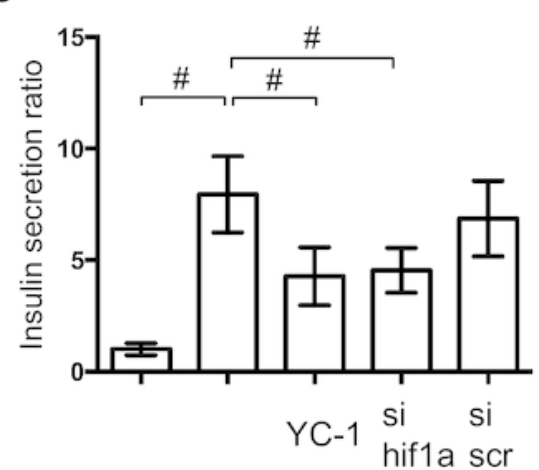

glucose $(\mathrm{mg} / \mathrm{dl})$

$40 \quad 400 \quad 400 \quad 400 \quad 400$
D

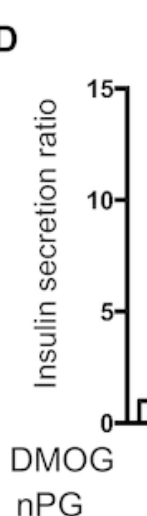

$P=0.919$

$P=0.009$

ISO

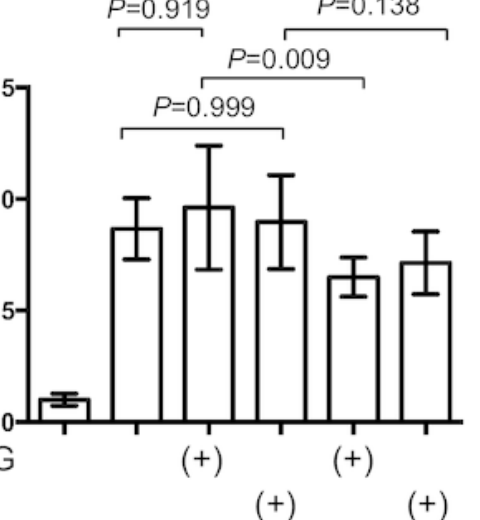

$(+) \quad(+)$ glucose $(\mathrm{mg} / \mathrm{dl})$

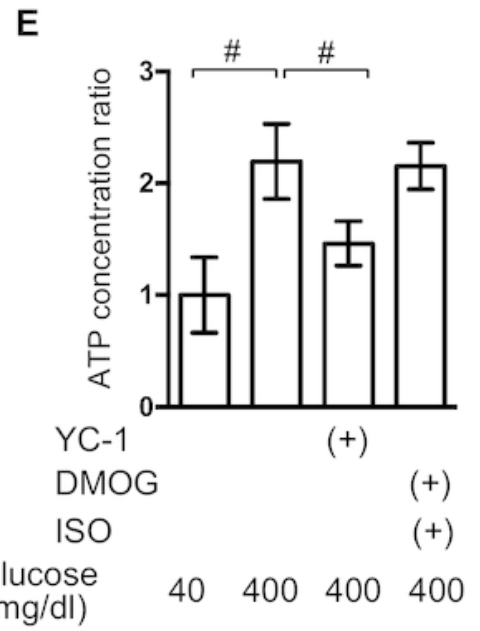




\section{8}

A schematic diagram indicating the mechanism of GSIS suppression by volatile anesthetics

\section{Figure 8: A schematic diagram indicating the mechanism of GSIS suppression by}

volatile anesthetics $A$. When the extracellular glucose concentration increases, pancreatic $\beta$-cell metabolism accelerates, leading to an increase in [ATPi]. As a result of these metabolic changes, the activity of ATP-dependent potassium channels $\left(\mathrm{K}_{\text {ATP }}\right)$ decreases; this causes membrane depolarization to the threshold potential at which voltage-dependent calcium channels open, allowing $\mathrm{Ca}^{2+}$ influx. The ensuing increase in cytosolic $\mathrm{Ca}^{2+}$ concentration triggers exocytosis of insulin-containing vesicles. B. Glucose-induced oxygen consumption is partially suppressed by the volatile anesthetics (isoflurane and sevoflurane). Mitochondrial oxygen consumption leads to cellular hypoxia, which activates HIF-1. The process is also inhibited by volatile anesthetics. The glucose-induced increase in the intracellular ATP level is inhibited by volatile anesthetics. Consequently, these compounds suppress GSIS, which is largely dependent on the intracellular ATP concentration.
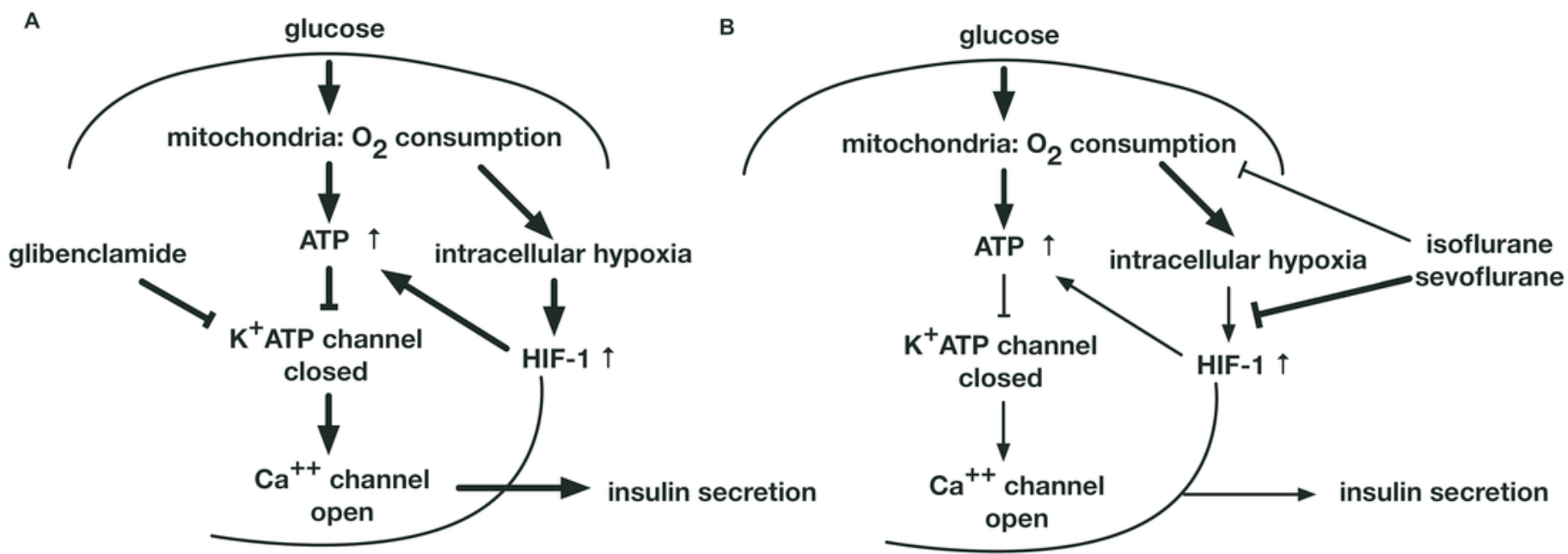